\title{
Research on Intagible Assets and Goodwill Valuation
}

\author{
Vladimir Kulil \\ VSB-Technical University of Ostrava, Faculty of Economics, Ostrava, Czech Republic
}

\section{Email address:}

vladimir.kuli1@vsb.cz

\section{To cite this article:}

Vladimir Kulil. Research on Intagible Assets and Goodwill Valuation. International Journal of Economic Behavior and Organization. Vol. 5, No. 1, 2017, pp. 20-24. doi: 10.11648/j.ijebo.20170501.14

Received: January 11, 2017; Accepted: February 17, 2017; Published: March 3, 2017

\begin{abstract}
The process of valuation of intangible influences was surveyed in China, Hong Kong, USA, Canada, Japan, Germany, UK, Poland, Russia and Western Europe. Situation in mentioned locations is similar, valuation of intangible influences has not been determined by a concrete list of items and there has not been established concrete clear process. The subject matter of this thesis was a proposal for a method of valuation of goodwill - special effects that will impact assets prices. It deals with proposed procedures for valuation of intangible assets, and definitions of such property. Special effects are in particular name, historical value design, quality of layout, security aspects, accessibility, conflict groups of inhabitants in or near the property, location, provenience and other. The value of goodwill can be calculated as the difference between the market value and the material value. Part of the methodology is a general proposal for a method how to divide the assets into tangible and intangible part and author's software VALUE-RATUS 2015.
\end{abstract}

Keywords: Market Value, Goodwill, Badwill, Price of Real Estate, Tangible Assets, Intangible Assets, Coefficient of Marketability

\section{Introduction}

Intangible assets valuation include certain specifics compared to cost assets. The specifics should be considered in the methodology and in final price. There exists a basic consensus in the way of tangible assets evaluation, in the case of intangible assets there is not. Aim is to introduce the scientific public with a different view on the essence of valuation. In scientific literature, focused valuation of real estate, cannot find a phrase intangible assets and real estate. Many appraisers consider buildings that are fixed with a land as purely tangible thing. So it is not. Regarding the price, a property consists of intangible parts, that have significant impact on valuation and this perspective is emphasized in this paper.

Goodwill is an economic term denoting the difference between the market value of the company and substance price, less any liabilities. Indicates a value, intangible assets such as customer relationships, reputation. Reflects market position, quality and especially tradition. Goodwill can distinguish two ways, on the goodwill of the original and secondary. Initial goodwill to create their own company's business activities, but not in the accounts of a company recognized because it is not reliably measurable. Secondary acquires goodwill on the acquisition of another company. Badwill is negative goodwill.

\section{Overview of a Current State of Knowledge}

Division of assets into tangible and intangible part has not been solved in available literature and methodologies worldwide. Experts have no definite foothold for valuation. This division is very important and necessary for valuation of property as a whole it brings clearer overview of a quality and inner essence of a corporate assets, tangible subjects and real estate. For example, it can represent an important measurement for investment decisions of investors. If the real estate as whole represents badwill, than it would be preferable to allocate capital to a location and environment with goodwill

Usually value of goodwill is determined by estimation with using complementary methods, there has not been reached a general consensus not in real concept goodwill 
meaning neither in its calculation. None of the definitions is fully accepted in general catholicity. For practical valuation it is necessary to define the way of valuation of special influences - goodwill and badwill clearly.

In an international environment aside the Czech Republic a survey focused on definitions and valuation of intangible assets was realized. In Germany the final list of special intangible influences depends on an expert, who defines and evaluates them. In Great Britain called Red Book (RICS) is the basic document for valuation, the process is similar. The process of valuation of intangible influences surveyed also in Poland, in Russia, Hong Kong, USA, Canada, Japan, China and Western Europe [1]. Situation in mentioned locations is similar, valuation of intangible influences has not been determined by a concrete list of items and there has not been established concrete clear process. In Slovakia intangible influences is part of price regulation [2] especially in the field of methods of location differentiation. Up to 21 factors of intangible effects for constructions and up to 22 factors for lands have been defined in Slovakia. The most detailed processes and unified definitions for intangible assets valuation abroad are in International valuation standards IVS, where the issue solved only at the general level without any concrete list of intangible special influences [3]. European valuation standards TEGoVA [4] have similar conception and they formed in order to be conform to standards IVS also in order to reach worldwide consensus in best practices in valuation process.

A good-quality system for intangible influences valuation according to price regulation [5] exists in the Czech Republic. Since 1997 system has been developing and finishing with the aim to approximate maximally administrative prices to market prices. In the area of special influences methodology introduced in Decree with appendixes is valid. For cost valuation under price regulation from 1997 till 2013 marketability coefficients Kp were valid. The coefficients represent relationship between real estate price agreed according to buying contract and their prices determined on the basis of price regulation transferred to the unified price level (appendix no. 39 of Decree). While valuating by comparative way in decree appendixes up to 35 items of intangible special effects were determined, but in practice up to 100 current effects can be determined.

\section{New Findings and Special Influences Valuation}

Following procedure for valuation of goodwill and badwill type of assets of enterprises resulting from mentioned model approaches appears as the most objective. Enterprise assets will be evaluated by comparative, yield and cost method. The price will be adjusted in each used method according to an influence of special effects, which means good or bad reputation and according to other special effects which influence usual market price. Other evaluated intangible assets of an enterprise (except goodwill) are included in the price if they really exist. On the basis of these data market price is appraised. Similarly, valuation of goodwill and badwill by using comparative, yield and cost, we must used for real estate. A price in each method we must adjusted by direct special influences, it means good reputation, bad reputation and other similar influences and it will influence the market price level. On the basis of this background market price will be appraised. The amount of goodwill $(G W)$ or badwill $(B W)$, is the difference market price $(C O)$ and cost price $(C C)$ as:

$$
\mathrm{GW}(\mathrm{BW})=\mathrm{CO}-\mathrm{CC} \text {. }
$$

The market value $C O$ is determined by multiplying the cost value $C C$ (replacement cost less depreciation, or material value) by marketability coefficient $K P$ according to the relationship

$$
\mathrm{CO}=\mathrm{CC} \times \mathrm{KP}
$$

it follows that

$$
\mathrm{KP}=\mathrm{CO} / \mathrm{CC}
$$

The marketability coefficient $K P$ is defined as the ratio between the average actual sales values achieved and the average cost prices of a comparable type of things at the particular time and location.

In context with intangible part of property the valuer's approach is significant. An approach should be not only technical, but except experiences valuer should have also an expert feeling for fair and objective assessment of the matter of the circumstances, which have an impact on a property price. So ethically right valuer processes are very important and it should be better integrated into the Czech law in the field of forensic experts. A judge is obliged by legal promise that he will decide conscientiously and fairly and since judge requires an expert opinion, an expert have to seek market price which is fair and according to the best conscience.

Ownership of created movable or construction means a possibility of any manipulation in conformity to the laws. Even if the constructions defined as immovable, we can move it to another land. Construction is possible built again. But certain depreciation exists here. Lifespan is maximally hundreds or several thousand years. This property can be destroyed, concretely its material and also non-material part. However, land as a part of the planet's surface, cannot be created, transferred od destroyed. The main component of land price is represented by non-material part of a land. Tangible part of a land price has minimal or zero price as it is more described in the following text.

Permanent vegetation is a part of the plot of land and has a material substance which can be determined by using cost, yield or comparative method especially in relation to economic benefit. Permanent vegetation also has an intangible component that is valuable as in the case of plots of land and buildings. It implies to special influences of actual demand and usability for the owner or potential buyer. An intangible component of permanent vegetation is 
represented by the landscape and aesthetic function, ensuring privacy and recreation, security, defense, windbreak function, protection against noise, odors, dust, pollutants, against inclement weather and climate, providing reinforcement of subsoil slope and land. Following factors belong also to this group: erosion as influences, hydrological function, oxygen production, the possibility of the existence of fauna, flora, production of fragrances, cultural and historical features, for example with protected trees, etc. [6].

\section{Methodology Proposal for Special Influences Valuation in the Field of Real Estate}

In the field of real estate, marketability coefficients $(K p)$ have been worked out for valuation with administrative price. Marketability coefficients $K p$ take into consideration location of structures and plots of land on the basis of statistical assessment of all realized sales in the Czech Republic. Location effect on price is very important. Administrative cost prices with $K p$ in some categories of property are multiplies of cost price determined without $K p$.

Utility value is clearly defined in a German literature: Utility value of real estate consists of a quality and location parts. Quality part of real estate refers to a technical quality and to the architectural design and equipment. Location part respects a structure of build-up area, traffic availability, availability of connection to local infrastructure, influence of noise, industrial emissions, influence of historical development of a town and so called very valuable addresses. Utility value of real estate is therefore critical item in relation to a price. According to Anglo-Saxon literature a goodwill has to be considered as documentary only if a long term income in context with goodwill can be expected. It assumed that for this property a buyer paid an extra charge, which is as an intangible asset supported by utility value [7]. Just so defined extra charge can be considered as special valuation of surveyed special intangible influences that help to create value of movables, real estate and enterprise. Intangible assets of goodwill type are the subject of financial reporting and accounting depreciation in enterprises, but in an international trade accounting rules are inconsistent. In the acquisition of enterprices a very significant sum for the goodwill can be reported. Acquisition also contain immovable assets, which are part of the intangible assets of firms. For example, when buying the American company Gerber Product Co. by Swiss company Sandoz Ltd. goodwill amounted to $3.2 \mathrm{bn}$. USD in transactions totaling 3.7 billion. USD, it is about $86 \%$ of the purchase price [6].

\section{List of the Groups of Special Influences}

Marketability coefficient $(K P)$ is a product of marketability coefficient $(K p)$ determined by Czech price regulation and index of additional special influences if they exist and have an impact on a price. If $K p$ is not determined or doesn't correspond to an average market price, then it can be determined by an expert appraisal for example with the help of statistical office data.

$$
\mathrm{KP}=\mathrm{K}_{\mathrm{p}} \times\left(1+\sum_{i=1}^{10} \mathrm{KPi} \% \times 0.01\right)
$$

Table 1. Intangible pricing influences.

\begin{tabular}{lll}
\hline Nr. & $\begin{array}{l}\text { Intangible pricing influences by modifying } \\
\mathbf{K}_{\mathrm{p}} \text { per item with detailed list itemization }\end{array}$ & $\begin{array}{l}\text { Recommended } \\
\text { range } \%\end{array}$ \\
\hline 1. & $\begin{array}{l}\text { Location favorableness in the locality } \\
\text { compared to the average of the locality }\end{array}$ & From $-10 \%$ to $+10 \%$ \\
2. & $\begin{array}{l}\text { Real estate name, prestigiosness, dominance } \\
\text { Historical value, cost of preservation of }\end{array}$ & From $-10 \%$ to $+10 \%$ \\
3. & $\begin{array}{l}\text { monuments } \\
\text { Architectonic rendering, the quality of } \\
\text { disposition, view }\end{array}$ & From $-10 \%$ to $+10 \%$ \\
4. & $\begin{array}{l}\text { Safety, users' privacy, conflict inhabitants in }-10 \% \text { to }+10 \% \\
\text { the surroundings }\end{array}$ & (From $-70 \%$ to \\
6. & $\begin{array}{l}\text { Danger of floods, landslides, damage from } \\
\text { transport, bad smells, air pollution }\end{array}$ & From $-10 \%$ to $+10 \%$ \\
7. & $\begin{array}{l}\text { Dangerous disposition and harmful material, } \\
\text { radon }\end{array}$ & From $-10 \%$ to $0 \%$ \\
8. & $\begin{array}{l}\text { Transport accessibility with respect to the } \\
\text { average standard in the surroundings }\end{array}$ & From $-10 \%$ to $+10 \%$ \\
9. $\quad \begin{array}{l}\text { Impact of terraced housing, a building inside a } \\
\text { row or at its end }\end{array}$ & From $-10 \%$ to $0 \%$ \\
10. $\begin{array}{l}\text { Pricing perspective of real estate and other } \\
\text { influences }\end{array}$ & From $-70 \%$ to $+10 \%$ \\
\hline
\end{tabular}

Source: [8]

Percentage range is recommended, and was determined by an expert estimation and calculations, according to general specialized literature for valuation. Also with regard to determined margins in previous Czech and Slovak regulations valid from 1977 to 2015 . Correction scale is proposed as $50 \%$ of recommended range in the case of advantage or disadvantage due to special influence and at the same time the scale is proposed as $100 \%$ of recommended range due to significant advantage or significant disadvantage. The ranges were proposed as a price adjustment compared to the average standard of real estate in a given location. Based on the calculations of special influences in the case of real estate, it is clear that the rate must be applied sensitively with the principle of prudence, depending on actual market demand.

Only influences with reasonably justifiable impact on property price can be calculated. Rates of surcharges and reductions percentage for those hundred items of proposed special influences need to be considered both in terms of cost, and particularly in terms of the market value - the usual market price, thus impact on the marketability of a specific property in real time and place. Recommended rates and limits are valid jointly for the whole collection of structures, plots of land and permanent vegetation. Final valuation of special influences will be realized by the sum of increases and reductions with conclusive justification. 


\section{Intangible Assets Ownership and Valuation}

\subsection{Ownership}

Who owns the permanent vegetation, buildings or landscaping (even future) on the plot of land, usually owns the goodwill or badwill relating to this land [8]. The price of land is also a reflection of the external construction work on adjacent land, or even in distant surrounding, for example in terms of access to the land or flood prevention measures, to build public facilities. Goodwill and badwill in this case, automatically become the property of the owner. Mentioned external investments have an impact on the owners ' property. It is a free acquisition of intangible assets. Only some cases of badwill can be compensated by an investor, usually only in the case of exceeding the health, sanitary and technical standards (e.g. dust, odors and noise from the road). Land without the possibility of any building, construction and technical adjustments without a permanent vegetation, which hasn't any use for a human even prospectively, hasn't any value for a human and any intangible part of the price.

\subsection{Yield Value VH}

For yield valuation assessment of goodwill (badwill) will be realized by a reasonable adjustment of the capitalization rate through adequate reduction or surcharges compared with an average standard of the real estate quality. An identical correction of the sum of the influences by the cost method is proposed as a standard level of capitalization, which is tied to the material component of the property, should be modified only by aspects of intangible assets, considering assets risk in the future. Capitalization rate $(P)$ used for calculating the yield value will be adjusted by the identical percentage according to price influences (adjustment of risk surcharge) compared to the standard character of the property, with an average capitalization rate $(k)$ and the average amount or profitability risk. Generally while using the calculation according to the formula for perpetual annuity the yield value is the ratio of net annual return $(C V)$ and $(P)$ capitalization rate as a percentage:

$$
\begin{gathered}
\mathrm{VH}=\mathrm{CV} / \mathrm{P} \% \\
\mathrm{P} \%=\mathrm{k} \%+0,01 \times\left(\sum_{i=1}^{10} \mathrm{KPi} \%\right) .
\end{gathered}
$$

\subsection{Comparative Value $P H$}

In this case the valuation will be realized as comparison towards standard etalon in relation to goodwill (badwill). Comparative value $(\mathrm{PH})$ will be adjusted by the rate $\pm \sum \mathrm{KPi}$ compared to an average comparative value of real estate $(\mathrm{Ph})$ without special influences. Using the indexes should be reasonably justified. Identical influences and rates of individual groups of items from no. 1 to no. 10 for comparison will be used. It is also possible to use a direct comparison with other property regarding existing special influences if there are resources for comparing the appropriate quality. However, it is necessary to take into account the need of comparing a large number of qualitative characteristics, which may generate significant mistakes with regard to the limited information on the compared properties which are available. A aforementioned method of comparison with average real estate etalon therefore appears as a more accurate method and in the latest phase it is recommended to adjust the results by extraordinary special influences:

$$
\mathrm{PH}=\mathrm{Ph} \times\left(1+\sum_{i=1}^{10} \mathrm{KPi} \% \times 0.01\right) .
$$

\subsection{Market Value CO}

According to cost, yield and comparative valuation mentioned in previous parts there will be realized an appraisal of market value. The amount of price of special influences - goodwill and badwill - will be the difference between market value of property and cost price without $K P$ (cost price $C C$ ). Amount of harm in connection with the easement will be counted as standard yield method and subtracted from the market value of the property. The maximum discount is not determined.

\subsection{Coefficient of an Intangible Asset}

From the concept of marketability coefficient $K P$ or $K p$ (in German-speaking countries a similar term market hopefulness is used) its fundamental as an index for determining the degree of special influences - intangible assets $(N M)$ in a positive or negative amount towards the current price $(C C)$ and usual market price - value of assets $(C O)$ as a whole is not obvious.

$$
\mathrm{CO}=\mathrm{CC}+\mathrm{NM} \text {. }
$$

Coefficient of an intangible asset $\left(K_{N M}\right)$ appears to be more accurate term. An intangible character of valued property results from the mentioned term and it shall not be determined as the estimated generally not well understood constant, which an expert established. This coefficient can be expressed by the following formula:

For real estate

$$
\mathrm{K}_{\mathrm{NM}}=(\mathrm{CC}+\mathrm{NM}) / \mathrm{CC} .
$$

For movables

$$
\mathrm{K}_{\mathrm{NM}}=(\mathrm{CC}+\mathrm{NM}) / \mathrm{CC} .
$$

For enterprises from the material value $(S)$

$$
\mathrm{K}_{\mathrm{NM}}=(\mathrm{S}+\mathrm{NM}) / \mathrm{S} \text {. }
$$

\section{New Methology}

Separate system of valuation tangible and intangible assets 
worked out [8]. For the field of special influences there were proposed and defined apposite terms goodwill and badwill for valuation analogically according to the terms used by economists and appraisal experts while appraising enterprises. Character and fundamental of marketability coefficients KP are clarified from the point of view of their relationship to tangible and intangible assets. Ten main areas and hundred items of intangible influences affecting real estate price are defined complexly. It is modular method influences are evaluated in percentage. A higher number of influences than 100 is possible, for practical use. However, it can be misleading.

Author created a software NEMO-RATUS 2015 [9] for practical use. Proposed procedures in the whole extend of valuation including table analysis of proposed hundred special influences for real estate with logarithmic regression and including intangible assets into cost, yield, comparative and market price are applied in the computer system. Market price of property is than divided automatically. into tangible and intangible part. For more details see http://www.ekf.vsb.cz/k166/cs/. Proposed procedures and detailed listing of special influences represent a comprehensive, practical and unequivocal support for the valuation practice of experts.

Real estates have only two parts of market price. It is costquantifiable tangible cost price, which is adjusted by intangible goodwill (GW) or badwill (BW), its price can only be appraised [10]. Intangible and relative character of special influences results from their external character impact. Proposed methodology enables to divide each movable and immovable property into tangible part (cost price) and intangible part (GW, BW) with sufficiently estimated accuracy for practical use. Then also enterprise assets can be newly divided into tangible and intangible part. Goodwill or badwill as a summary of specific intangible impacts on the market price is calculated as the difference between the market value of the property and its cost price. This rule applies generally to movable property, immovable property and enterprises.

Plots of land price is represented by all rights related to human activities on a land including construction and construction rights. Plot of land is to full extend intangible asset only of goodwill type. Land price is not determined randomly, but is a reflection ("shadow") of values of specific structures located there or planned or it is a reflection of future use. Owner of the intangible part of the price of real estate is an investor, that plan and finance modifications of the property. It may not always be real estate owner. Goodwill or badwill caused by investments or investment plans in the area of valuated real estate passes automatically and free of charge to the ownership of the property owner.

\section{Conclusion}

Aim of the paper was to work out a proposal for valuation of special influences that have an impact on real estate price. Controllable procedures for the valuation of intangible assets were proposed. System of valuation with direct implementation in cost [11], yield and comparative methods from which we can estimate the market value was proposed. In case of real estate special influences are defined mostly as good or bad name of locality real estate, historical value, design, quality of layout, safety aspects, transport accessibility, conflict inhabitants in the surroundings, influence of terraced house, other influences and price perspective. Terms goodwill (GW) for each surveyed special influence in case of positive impact and badwill (BW) in case of negative impact were defined.

\section{References}

[1] SEABROOKE, W., KENT, P. a HWEE, H.: (2004). International Real Estate an Institutional Approach. UK, USA, Australia: Blackwell Publishing Ltd. [monograph]

[2] DECREE No. 492/2004 Coll. with implementing decrees of the Ministry of Justice of the Slovak Republic on the Determination of General Value of Real Estate.

[3] IVS - International Valuation Standards Committee: International Valuation Standards, 2011, IVSC, London, UK 2011, ISBN: 978-0-9569313-0-6.

[4] EVS - European Valuation Standards, 5. edition 2003.

[5] CZECH ACT on Property Valuation No. 151/1997 Coll. with implementing decrees No. 303/2013 Coll., No. 199/2014 Coll., No. 345/2015 Coll. and No. 443/2016 Coll.

[6] SHETTY, A. (1995). Finance and Integrated Gglobal Approach. USA: Austen Press, Homewood. [monograph]

[7] HORNE VAN, J. Financial Management and Policy. New Jersey, USA: Englewood Cliffs, 1989, p. 647.

[8] KULIL, V. (2015). Goodwill and Valuation. Saarbrücken, Germany: OmniScriptum GmbH \& Co. KG. [monograph]

[9] KULIL V. (2015). Software for goodwill valuation VALUERATUS. Ostrava, Czech Republic: http://www.ekf.vsb.cz/k166/cs/.

[10] SMITH, G., RUSSELL, L. (1989-2010). Valuation of Intellectual Property and Intangible Assets. New York, USA: John Wiley and Sons, ISBN 0-471-54950-9.

BRADAC, A. (1999). Forensic engineering. Brno, Czech Republic: CERM, ISBN 80-7204-133-9. 